ISSN 2524-0943 ВIСНИК Львівської національної академії мистецтв. Вип. 42. 2019

удК 74/748.5

Nataliya Benyakh

Senior Lecturer of the Art Wood

Department of Lviv National Academy of Art,

Candidate of Art Criticism

https://orcid.org/0000-0002-2578-0555

\section{Challenges and prospects for the world studio glass development: based on the results of the International Scientific and Practical Conference-presentation "World Studio Glass. Tradition and Experiment"}

\begin{abstract}
Анотація. Наталія Бенях. Виклики та перспективи розвитку світового студійного скла: за результатами Міжнародної науково-практичної конференції-презентації «Світове студійне скло. Традиція та експеводночас, загальносвітовими для всіх представників сучасного декоративного мистецтва. Це виклики, перед якими постає і скляна промисловість в цілому, і окремий художник чи школа.
\end{abstract} римент». Міжнародний рух студійного скла, який виник у 1960-х рр. і став важливим явищем у новітній історії декоративного мистецтва, сьогодні постає перед новими викликами сучасності. Рух студійного скла спричинив появу нового поняття в сучасному мистецтві - образотворчого скла, яке впродовж останніх десятиліть сформувало нові мистецькі вартості. Незважаючи на глобальний характер поширення студійного руху, спільний вектор розвитку художнього скла в напрямку звільнення від промислової залежності ставить перед художниками-склярами дизайнерами, національними школами нові вимоги та виклики. У сучасному склі переважає прагнення до образності та ідейності. Національні школи мають чітко виражену ідентичність і вирізняються власною індивідуальністю. Міжнародна науково-практична конференція-презентація «Світове студійне скло. Традиція та експеримент», що відбулась у рамках XI Міжнародного симпозіуму гутного скла у Львові стала тим майданчиком обміну досвідом між художниками-склярами з усього світу. Що три роки митці зустрічаються у Львові, демонструють свої вміння на базі майстерень єдиної в Україні кафедри художнього скла та розповідають про свої напрацювання громадськості. Творчі зустрічі відбувались у галереї
Львівської національної академії мистецтв у період 3 7 до 10 жовтня 2019 року. Проєкт було реалізовано за підтримки Українського культурного фонду.

У доповідях, виголошених упродовж чотирьох днів роботи конференції, порушувалися актуальні питання розвитку сучасного художнього скла, професійної освіти; формування творчих майстерень і мистецьких угрупувань; ролі фестивалів, симпозіумів у розвитку художнього скла; використання нових технік, технологій у постіндустріальну епоху. Загалом доповідачі проаналізували широке коло проблем і явищ студійного скла, поділились власними спостереженнями і грунтовними розвідками окремих технологічних процесів.

Учасники конференції у доповідях торкались важливих питань діалогу культур, розвитку сучасного студійного руху, впливу новітніх технологій на традиційні методи обробки. Значна увага приділялась обговоренню основних тенденцій розвитку художнього склярства. Доповідачі звертали увагу на гострі виклики сучасності, що постають перед художниками-склярами, і які $\epsilon$,

Ключові слова: студійне скло, конференція, симпозіум, авторське скло

$\mathrm{T}$ he International Scientific and Practical Conference-presentation of the creativity of world-famous glass artists "World Studio Glass. Tradition and Experiment" was held within the frames of the XI International Blown Glass Symposium in Lviv. Every three years the artists meet in Lviv, demonstrate their skills on the workshop basis of the only Glass Art Department in Ukraine and tell the public about their experience. Creative meetings took place in the Gallery of Lviv National Academy of Art during the period from October 7 to October 10, 2019. The project was implemented with the support of the Ukrainian Cultural Fund.

At the Conference, the well-known glass artists and designers from Iceland, the USA, Lithuania, Latvia, Hungary, Belarus, Turkey and Russia represented their works. In particular, the reports were made by Baiba Dzenīte (Latvia) - SETO international ceramics and glass art exchange program. Cultural dialogue 2018-2019; Elena 
Atrashkevich-Zlatkovic (Belarus-Serbia) - Glass in modern art practices of Belarus and Serbia; Valda Verikaite (Lithuania) - Glass festival Vitrum Balticum; Ufuk Akbey (Turkey) - The usage of phosphorescent pigments in artistic glass works; Sigrun O. Einarsdottir (Iceland) - "Images on glass: thoughts and inspirations"; Angus Powers (USA) - "Glass Art ENGINE”; Ekrem Kula (Turkey) - Glass Foam works created from studio and sodalime-silicate recyclable glass; James Ronner (USA) - Artist talk and The Studio at Corning Museum of Glass; Indre Stulgaite Kriukiene (Lithuania) - GLASS JAZZ Symposiums; Paulius Rainys (Lithuania) - Postindustrial glass art movement. Cultural phenomenon or an effort to keep the tradition?; Laura Seryte (Lithuania) - Collective memory as an impulse of creativity; Inguna Audere (Latvia), Michael Rogers (USA) IRMA Collaborative Creative Activity; Tamás Ábel (Hungary) - Technological advances in Hungarian Glass Art; Maria Usova (RF), Ceramics and Glass Department of the Saint Petersburg Stieglitz State Academy of Art and Design.

In the reports, delivered during four days of the Conference, the current issues of the contemporary glass art development and professional education (James Ronner, Elena Atrashkevich-Zlatkovic, Maria Usova), the formation of creative workshops and artistic groups (Angus Powers, Anda Munkevica, Inguna Audere, Michael Rogers), the roles of festivals, symposiums in the glass art development (Baiba Dzenīte, Valda Verikaite, Indre Stulgaite), the use of new techniques and technologies in postindustrial era (Ekrem Kula, Paulius Rainys, Sigrun O. Einarsdottir, Tamás Ábel, Ufuk Akbey) were discussed. Generally, the speakers analysed a wide range of problems and phenomena of the studio glass, shared their own observations and considerable researches of individual technological processes.

Baiba Dzenite shared her impressions of the residence in the city of Seto (Japan) that is an ancient ceramic centre of Japan, where artistic symposiums, residences and festivals for glass artists from all over the world are held every year. This centre of Japanese ceramic art became a location for cooperation of famous artists and students and experience exchanging. Each participant complemented the world cultural map with his creativity.
Valda Verikaite and Indre Stulgaite presented the results of holding two international festivals in Lithuania - Glass festival Vitrum Balticum and GLASS JAZZ Symposium. Today, art festivals, symposiums and residences have become an important factor in the development of contemporary glass. Such form of cooperation of the artists promotes the actualization of new artistic practices.

The postindustrial movement of studio glass opens new ways for development of this kind of art and places new demands on contemporary glass blowers and artists. Paulius Rainys considered in his report this phenomenon in contemporary glass under the prism of traditions and innovations. The speaker rose for the listeners the significant questions concerning the activities of glassworks and workshops. He defined the main challenges facing the traditional forms of art glass processing.

Tamás Ábel represented the creativity of the following contemporary Hungarian glass artists: György Gáspár, László Lukácsi, Peter Borkovic, Zsuzsanna Kóródi, Tamás Ábel, etc. Special attention is focused on the author's works and techniques of performance, usage of contemporary technologies in Hungarian glass art. In particular, the speaker marked while depicting his works that he 'always searched for technological difficulties and concepts of social importance. From glass sculptures of smaller scale, I turned to larger wall mirror figures, and, recently, I have been working at large scale installations...'.

The speakers from Turkey represented the author's techniques of art glass processing, namely: the works by Ekrem Kula, made of studio and soda-lime-silicate recyclable glass, and Ufuk Akbey, who uses phosphorescent pigments.

The participants in the Conference touched in their reports on the important issues of culture dialogue, the development of contemporary studio movement, the impact of the latest technologies on traditional methods of processing. Much attention was paid to the discussion of the main tendencies of glass art development. The speakers concentrated on acute challenges of modernity, which glass artists are faced with, and which are, at the same time, universal for all representatives of contemporary decorative art. These are the challenges for glass industry as a whole and for an individual artist or school 
Challenges and prospects for the world studio glass development: based on the results of the International Scientific and Practical Conference-presentation "World Studio Glass. Tradition and Experiment"

as well. However, these challenges become the driving force, which allows using and adapting new technologies in contemporary glass, and outlines the new prospects for the development of this material. They made the artists search the ways of overcoming problematic issues not just in technology, but in figurative solution of the works as well. Some speakers represented author's techniques of art glass processing, shared their experience of technological experiments.

Over the centuries, glassmaking has been gaining its place among the art crafts; there were the periods of its rise and decline. Glass blowers tried to compete with craftsmen of other kinds of decorative and applied art, they established craft artels, workshops and manufactories and adjusted to economic and sociohistorical conditions.

Contemporary glass art is a combination of the tradition and author's experiment of an artist. The range of works is very wide: from small handicrafts to landscape glass, sculptures, performance, installations and so on. The contemporary glass is utilitarian, duplicated works and original author's projects. This is a constant balancing between the tradition and new experiments, between the genres and kinds of art.

Such creative meetings, conferences, presentations and dialogues are extremely important today for the experience exchange and the development of new directions of world studio glass, which goes far beyond the limits of applied and visual directions and design.

1. Angus Powers. Bergren Forum GLASSARTENGINE. URL: https://www.alfred. edu/student-life/arts-events/calendar/2019/12/ bergren-forum---glassartengine.html

2. Barovier Mentasti R. Glass Throughout Time: History and Technology of Glassmaking from the Ancient World to the Present. Skira, First Edition edition. 2003. $288 \mathrm{~s}$.

3. Biography: Angus Powers / Corning Museum of Glass URL: https://www.cmog.org/bio/anguspowers

4. Corning Museum of Glass: official website. URL: http://www.cmog.org

5. Corning Museum of Glass. Sigrún Ólöf Einarsdóttir URL: https://www.cmog.org/library/glas-tra-de-sren-larsen-sigru-n-einarsdo-ttir-o-lo-f-einarsdottir-glass-threads-s-ren
6. International glass art festival 'Vitrum Balticum 2017. Trap!' at Meno parkas gallery. URL: http:// echogonewrong.com/exhibitions-internationalglass-art-festival-vitrum-balticum-2017-trapmeno-parkas-gallery/

7. Jennings T. Glass: Material Matters. Lacma. Academic Press 2009. 480 p.

8. Michael Rogers. URL:https://www.michaelrogersart. site/about

9. Ufuk Akbey / Galery Soyut. URL: https://www. galerisoyut.com.tr/ufuk-akbey-2016/

10. Seto International Ceramic \& Glass Art Exchange Program. Baiba Dzenīte. URL: http://www.seto-cul. jp/scga/e/18-19/baiba.html

11. Pamenkalnio Galerija. Laura Šèrytè. URL: http:// www.dsgalerija.lt/index.php/pageid/690

\section{References}

1. Angus Powers. (2019). Bergren Forum GLASSARTENGINE. Retrieved from: https://www.alfred.edu/student-life/artsevents/calendar/2019/12/bergren-forum--glassartengine.html

2. Barovier Mentasti, R. (2003). Glass Throughout Time: History and Technology of Glassmaking from the Ancient World to the Present. Skira.

3. Biography: Angus Powers / Corning Museum of Glass Retrieved from: https://www.cmog.org/bio/ angus-powers

4. Corning Museum of Glass: official website. Retrieved from: http://www.cmog.org

5. Corning Museum of Glass. Sigrún Ólöf Einarsdóttir Retrieved from: https://www.cmog.org/library/ glas-tra-de-s-ren-larsen-sigru-n-einarsdo-ttir-olo-f-einarsdo-ttir-glass-threads-s-ren

6. International glass art festival 'Vitrum Balticum 2017. Trap!' at Meno parkas gallery. Retrieved from: http://echogonewrong.com/exhibitionsinternational-glass-art-festival-vitrum-balticum2017-trap-meno-parkas-gallery/

7. Jennings, T. (2009). Glass: Material Matters. Lacma. Academic Press.

8. Michael Rogers. Retrieved from: https://www. michaelrogersart.site/about

9. Ufuk Akbey / Galery Soyut. Retrieved from: https:// www.galerisoyut.com.tr/ufuk-akbey-2016/

10. Seto International Ceramic \& Glass Art Exchange Program. Baiba Dzenīte. (2018-2019). Retrieved from: http://www.seto-cul.jp/scga/e/18-19/baiba.html 
Nataliya Benyakh

11. Pamenkalnio Galerija. Laura Šèrytè. Retrieved from: $\quad$ http://www.dsgalerija.lt/index.php/ pageid/690

\section{ANNOTATION}

Nataliia Benyakh. Challenges and prospects for the world studio glass development: based on the results of the International Scientific and Practical Conference-presentation "World Studio Glass. Tradition and Experiment". The international studio glass movement, which emerged in the 1960s and became an important phenomenon in the recent history of decorative arts, today faces new challenges of today. The movement of studio glass has led to the emergence of a new concept in contemporary art - fine glass, which in recent decades has formed new artistic values. Despite the global nature of the spread of the studio movement, the common vector of the development of art glass in the direction of liberation from industrial dependence poses new requirements and challenges to glass artists, designers, national schools. The desire for imagery and ideology prevails in modern glass. National schools have a clear identity and are distinguished by their own individuality. The International Scientific and Practical Conference-presentation of the creativity of world-famous glass artists "World Studio Glass. Tradition and Experiment" was held within the frames of the XI International Blown Glass Symposium in Lviv. Every three years the artists meet in Lviv, demonstrate their skills on the workshop basis of the only Glass Art Department in Ukraine and tell the public about their experience. Creative meetings took place in the Gallery of Lviv National Academy of Art during the period from October 7 to October 10,
\end{abstract}

2019. The project was implemented with the support of the Ukrainian Cultural Fund.

In the reports, delivered during four days of the Conference, the current issues of the contemporary glass art development and professional education, the formation of creative workshops and artistic groups, the roles of festivals, symposiums in the glass art development, the use of new techniques and technologies in postindustrial era6, were discussed. Generally, the speakers analysed a wide range of problems and phenomena of the studio glass, shared their own observations and considerable researches of individual technological processes.

The participants in the Conference touched in their reports on the important issues of culture dialogue, the development of contemporary studio movement, the impact of the latest technologies on traditional methods of processing. Much attention was paid to the discussion of the main tendencies of glass art development. The speakers concentrated on acute challenges of modernity, which glass artists are faced with, and which are, at the same time, universal for all representatives of contemporary decorative art. The range of works is very wide: from small handicrafts to landscape glass, sculptures, performance, installations and so on. The contemporary glass is utilitarian, duplicated works and original author's projects. This is a constant balancing between the tradition and new experiments, between the genres and kinds of art.

Key words: studio glass, conference, symposium, studio movement 